\title{
The Association of Parathyroid Hormone Related Protein and Vitamin D Level with Serum Calcium Ion in Acute Leukemia Patients
}

\author{
Niniek Wiendayanthi, MI. Diah Pramudianti, Yuwono Hadisuparto
}

Department of Clinical Pathology, Faculty of Medicine, Sebelas Maret University/Clinical Laboratory Installation, Dr. Moewardi Public Hospital, Surakarta, Indonesia. E-mail: nike010678@gmail.com

\begin{abstract}
Acute leukemia is bone marrow clonal cell malignancy. One of its complications is hypercalcemia. Parathyroid Hormone-Related Protein (PTHrP) activities involve the regulation of Calcium (Ca) metabolism. Vitamin D is a steroid involved in Ca homeostasis and bone mineralization. This study aimed to analyze PTHrP and vitamin D levels with serum calcium ion in acute leukemia. A cross-sectional study was performed in Clinical Pathology Dr. Moewardi General Hospital Surakarta between July and August 2019, consisting of 41 subjects with new acute leukemia who were diagnosed based on bone marrow puncture and or immunophenotyping result. The cut-off value of $\mathrm{Ca}$ ion serum and PTHrP level were determined with a Receiver Operating Curve (ROC). The data were analyzed with a $2 \times 2$ table, followed by multivariate logistic regression analysis, and $p<0.05$ was considered significant. Statistical analysis showed the median age of 25 (2-68) years, 23 (56.10\%) $\mathrm{ALL}$, and 18 (43.90\%) non-ALL patients. The median of $\mathrm{Ca}$ ion and PTHrP were $1.08(0.84-1.21) \mathrm{mmol} / \mathrm{l}$ and 307.52 (20.77-1104.26) $\mathrm{pg} / \mathrm{mL}$, respectively. The mean level of vitamin D was $26.45 \pm 11.40 \mathrm{ng} / \mathrm{mL}$. Bivariate analysis showed that PTHrP levels $\geq 110.09 \mathrm{pg} / \mathrm{mL}$ and vitamin $\mathrm{D} \geq 20 \mathrm{ng} / \mathrm{mL}$ were related to serum Ca ion $\geq 1.07 \mathrm{mmol} / \mathrm{l}$ (PR 4.675; $95 \% \mathrm{CI}$ : 1.211-18.041; $p=0.021$ and PR 5.143; 95\% CI: 1.279-20.677; $p=0.017$ ). Multivariate analysis showed that PTHrP $\geq 110.09 \mathrm{pg} / \mathrm{mL}$ and vitamin $D \geq 20 \mathrm{ng} / \mathrm{mL}$ were associated with serum Ca ion $\geq 1.07 \mathrm{mmol} / \mathrm{l}$. There was a significant association between PTHrP, vitamin D level, and serum Ca ion in acute leukemia patients.
\end{abstract}

Keywords: Acute leukemia, hypercalcemia, parathyroid hormone-related protein, vitamin D

\section{INTRODUCTION}

Acute leukemia is a hematologic malignancy characterized by proliferation that leads to the accumulation of immature cells in the bone marrow and peripheral blood. Acute leukemia is classified into Acute Lymphoblastic Leukemia and Acute Myeloblastic Leukemia (ALL and AML). The etiology of leukemia is not clearly elucidated. It is characterized by the growth of young cells (blasts). In Indonesia, leukemia cases rank fifth among all malignancies in general. Acute lymphoblastic leukemia is most common in children, whereas AML increases with age. ${ }^{1,2}$

An acute leukemia diagnosis is based on several examinations, such as the morphology of bone marrow aspiration, immunophenotyping, cytogenetic and molecular analysis. The gold standard test for the diagnosis would be the morphology of Bone Marrow Puncture (BMP) if $>20 \%$ of blast cells were found. ${ }^{3}$

Hypercalcemia is a leukemia complication that must be considered. The incidence of hypercalcemia in acute leukemia is rare; however, it can cause an emergency condition. The mechanism of hypercalcemia in acute leukemia, which generally depicts humoral patterns, which depend on PTHrP, hypercalcemia mediated by osteolytic metastases, secondary hypercalcemia due to excessive increases in vitamin $\mathrm{D}$, and PTH-mediated hypercalcemia. ${ }^{4,5}$

Parathyroid hormone-related protein is a poly hormone that functions as an endocrine, autocrine, paracrine, and intracrine hormone. Parathyroid hormone-related protein activity involves the normal regulation of the metabolism of $\mathrm{Ca}$. Parathyroid hormone-related protein production is increased due to tumor cells, causing bone resorption to exceed formation. Bone resorption is stimulated beyond a mere formation, leading to increased Ca levels. ${ }^{6,7}$

Vitamin $D$ is an inactive hormone and must be preceding metabolized. The first hydroxylation occurs in the liver to form $25(\mathrm{OH}) \mathrm{D}$ or calcidiol, the second hydroxylation occurs in the kidneys, and the most active form is $1.25(\mathrm{OH}) 2 \mathrm{D}$ or calcitriol. Vitamin $\mathrm{D}$ causes increased absorption of $\mathrm{Ca}$ in the intestine 
and increases osteolytic bone resorption, increasing serum Ca levels. ${ }^{8,9}$

\section{METHODS}

This cross-sectional study was performed in the Clinical Pathology Laboratory of Dr. Moewardi Hospital from July to August 2019. The subjects were patients diagnosed with new acute leukemia based on BMP and or immunophenotyping results.

The study subjects' inclusion criteria were new patients diagnosed with acute leukemia based on BMP and/or immunophenotyping, males, females, children, and adults who agreed to participate in the study by signing informed consent. Criteria for the exclusion of study subjects were a history of kidney disease, bone disorders, history of drug use such as Antacids, androgen hormones, Ca salts, Ergocalciferol, hydralazine, lithium, PTH, thiazide diuretics, thyroid hormones, vitamin D, Acetazolamide, Albuterol, anticonvulsants, Asparaginases, Aspirin, calcitonin, cisplatin, corticosteroids, estrogens, heparin, laxatives, magnesium salts, and oral contraceptives for a long time, obtained from anamnesis or medical record data, pregnant and/or lactating females, and history of another malignancy or were suffering from it for an extended period.

The data of subject characteristic data were presented as mean and standard deviation when the conditions were met. To determine the strength of the relationship between PTHrP levels, vitamin D, and serum $\mathrm{Ca}$ ions, bivariate analysis and multivariate analysis using logistic regression were used to control other variables that might affect serum $\mathrm{Ca}$ ion levels, including age and type of leukemia. Statistical analysis was carried out using a computer program, with significant $p$-value 0.05 and 95\% CI.

Research permission was obtained from the Health Research Ethics Committee of the Faculty of Medicine, Sebelas Maret University/Dr. Moewardi, Surakarta, with number 914/VII/HREC/2019.

\section{RESULTS AND DISCUSSION}

Forty-one patients met our inclusion criteria. Cut-off of Ca ion and PTHrP levels using the ROC curve with the area below the curve obtained were $1.07 \mathrm{mmol} / \mathrm{l}$ with AUC 0.542 (95\% CI: 0.362-0.722; $\mathrm{p}=0.646)$ and $110.09 \mathrm{pg} / \mathrm{mL}$ with AUC 0.611 (95\% CI: 0.436-0.786), respectively. The basic characteristics of the study subjects (Table 1 ) consisted of 18 (43.90\%) male and 23 (56.10\%) female patients. The mean hemoglobin of acute leukemia patients in this study was $9.06 \pm 1.73 \mathrm{gr} / \mathrm{dL}$, while the median of leukocytes, platelets, and creatinine were 32.20 (0.70-313.60) 103/mL, 42 (5-309) 103/mL and 0.6 (0.2-1.2) $\mathrm{mg} / \mathrm{dL}$, respectively.

The median age of patients was 25 (2-68) years. The BMP test showed 23 (56.1\%) subjects diagnosed with ALL and 18 (43.9\%) diagnosed with non-ALL. Ca ion and PTHrP levels of acute leukemia patients In this study ranged from a median of 1.08 (0.84-1.21 mmol/l) to 307.52 (20.77-1104.26) pg/mL respectively, while the mean of vitamin $D$ levels was $26.45 \pm 11.40 \mathrm{ng} / \mathrm{mL}$ (Table 2).

Bivariate analysis showed a significant association between PTHrP levels $\geq 110.09 \mathrm{pg} / \mathrm{mL}$ with serum Ca ion levels $\geq 1.07 \mathrm{mmol} / \mathrm{l}$, and between vitamin D levels $\geq 20 \mathrm{ng} / \mathrm{mL}$ with serum Ca ion levels $\geq 1.07 \mathrm{mmol} / \mathrm{l}$ with a prevalence ratio of $4.675(95 \%$ CI: $1.211-18.041 ; p=0.021)$ and a prevalence ratio of 5.143 (95\% CI: 1.279-20.677; $p=0.017$ ) (Table 3).

Multivariate logistic regression analysis of the variables that might affect $\mathrm{Ca}$ ion levels, both with adjustments to vitamin D alone. Adjustments with other variables such as age and type of leukemia, showed an association between PTHrP levels $\geq 110.09$ $\mathrm{pg} / \mathrm{mL}$ and vitamin $\mathrm{D} \geq 20 \mathrm{ng} / \mathrm{mL}$ with serum $\mathrm{Ca}$ ion levels $\geq 1.07 \mathrm{mmol} / \mathrm{l}$ ( $\mathrm{PR}=0.186 ; 95 \% \mathrm{CI}$ : 0.038-0.899; $\mathrm{p}=0.036$ and $\mathrm{PR}=0.116 ; 95 \% \mathrm{CI}: 0.017-0.801$; $\mathrm{p}=0.029$ ). However, there was no significant association between age, type of leukemia, and serum Ca ions in acute leukemia patients (Table 4).

Table 1. Essential characteristics of the research subject

\begin{tabular}{|c|c|c|c|}
\hline Variable & $\mathbf{N}(\%)$ & Mean \pm SD & Median (min-max) \\
\hline \multicolumn{4}{|l|}{ Gender } \\
\hline Male & $18(43.90 \%)$ & & \\
\hline Female & $23(56.10 \%)$ & & \\
\hline $\mathrm{Hb}(\mathrm{g} / \mathrm{dL})^{\mathrm{b}}$ & & $9.06 \pm 1.73$ & \\
\hline Leukocyte (thousand/mL) & & & $32.20(0.70-313.60)$ \\
\hline Platelet (thousand/mL) ${ }^{a}$ & & & $42(5-309)$ \\
\hline Creatinine $(\mathrm{mg} / \mathrm{dL})^{\mathrm{a}}$ & & & $0.60(0.20-1.20)$ \\
\hline
\end{tabular}


Table 2. Characteristics of research variables

\begin{tabular}{|c|c|c|}
\hline Variable & $\mathbf{N}(\%)$ & Mean \pm SD/Median (min-max) \\
\hline Age & & $25(2-68)$ \\
\hline$<18$ y.o & $21(51.22 \%)$ & $7(2-16)$ \\
\hline$\geq 18$ y.o & $20(48.78 \%)$ & $39(25-68)$ \\
\hline \multicolumn{3}{|c|}{ Type of leukemia acute } \\
\hline ALL & $23(56.10 \%)$ & \\
\hline Non-ALL & $18(43.90 \%)$ & \\
\hline Ion $\mathrm{Ca}(\mathrm{mmol} / \mathrm{L})^{\mathrm{a}}$ & & $1.08(0.84-1.21)$ \\
\hline$\geq 1.07 \mathrm{mmol} / \mathrm{l}$ & 25 (60.97\%) & $1.13(1.08-1.21)$ \\
\hline$<107 \mathrm{mmol} / \mathrm{l}$ & $16(39.03 \%)$ & $0.99(0.84-1.07)$ \\
\hline PTHrP (pg/dL) ${ }^{a}$ & & $307.52(20.77-1104.26)$ \\
\hline$\geq 110.09 \mathrm{pg} / \mathrm{mL}$ & $22(53.66 \%)$ & $556.93(110.09-1104.26)$ \\
\hline$<110.09 \mathrm{pg} / \mathrm{mL}$ & 19 (46.34\%) & 84.75 (20.77-109.34) \\
\hline Vitamin $D(\mathrm{ng} / \mathrm{mL})^{b}$ & & $26.45 \pm 11.40$ \\
\hline$\geq 20 \mathrm{ng} / \mathrm{mL}$ & $27(65.85 \%)$ & $32 \pm 8.50$ \\
\hline$<20 \mathrm{ng} / \mathrm{mL}$ & $14(34.15 \%)$ & $14.49 \pm 4.65$ \\
\hline
\end{tabular}

Table 3. $2 \times 2$ table between serum PTHrP levels, vitamin D and other variables that might affect serum Ca ion levels

\begin{tabular}{|c|c|c|c|c|}
\hline \multirow{2}{*}{ Variable } & \multicolumn{2}{|c|}{ Ca Ion (mmol/l) } & \multirow{2}{*}{ Serum PR $(95 \%$ CI) } & \multirow{2}{*}{$\mathbf{p}$} \\
\hline & $\geq 1.07$ & $<1.07$ & & \\
\hline \multicolumn{5}{|l|}{ Age } \\
\hline$<18$ y.o & 13 & 7 & $1.393(0.395-4.917)$ & 0.606 \\
\hline$\geq 18$ y.o & 12 & 9 & & \\
\hline \multicolumn{5}{|c|}{ Type of acute leukemia } \\
\hline ALL & 15 & 8 & $1.500(0.423-5.315)$ & 0.529 \\
\hline Non ALL & 10 & 8 & & \\
\hline \multicolumn{5}{|l|}{ PTHrP } \\
\hline$\geq 110.09 \mathrm{pg} / \mathrm{mL}$ & 17 & 5 & $4.675(1.211-18.041)$ & $0.021^{*}$ \\
\hline$<110.09 \mathrm{pg} / \mathrm{mL}$ & 8 & 11 & & \\
\hline \multicolumn{5}{|l|}{ Vitamin D } \\
\hline$\geq 20 \mathrm{ng} / \mathrm{mL}$ & 20 & 7 & $5.143(1.279-20.677)$ & $0.017^{*}$ \\
\hline$<20 \mathrm{ng} / \mathrm{mL}$ & 5 & 9 & & \\
\hline
\end{tabular}

Table 4. The logistic regression analysis results of serum PTHrP levels, vitamin D, and other variables that might affect serum Ca ion levels

\begin{tabular}{llll}
\hline Variable & PR & 95\%CI & p \\
\hline Model 1 & & & $0.042^{*}$ \\
PTHrP $\geq 110,09 \mathrm{pg} / \mathrm{mL}$ & 0.223 & $0.053-0.947$ & $0.035^{*}$ \\
Vitamin D $\geq 20 \mathrm{ng} / \mathrm{mL}$ & 0.203 & $0.046-0.897$ & $0.030^{*}$ \\
Model 2 & & & $0.024^{*}$ \\
PTHrP $\geq 110.09 \mathrm{pg} / \mathrm{mL}$ & 0.176 & $0.037-0.844$ & 0.335 \\
Vitamin D $\geq 20 \mathrm{ng} / \mathrm{mL}$ & 0.140 & $0.025-0.770$ & $0.036^{*}$ \\
Type of acute Leukemia & 2.386 & $0.407-13.974$ & $0.029^{*}$ \\
Model 3 & & & 0.459 \\
PTHrP $\geq 110.09 \mathrm{pg} / \mathrm{mL}$ & 0.86 & $0.038-0.899$ & 0.659 \\
Vitamin D $\geq 20 \mathrm{ng} / \mathrm{mL}$ & 0.116 & $0.017-0.801$ & $0.308-13.515$ \\
Type of acute leukemia & 2.041 & $0.221-10.866$ & \\
Age & 1.550 & & \\
\hline
\end{tabular}


Data on the characteristics of the research subjects showed a predominant number of males compared to females. Another study with the similar results was obtained in the study of Sanchez et al. in Mexico, which showed 742 (51.80\%) females and 690 (48.2\%) males of total 1,432 respondents. ${ }^{10}$ Contrastingly, research by Hasanbegovic et al. in Bosnia-Herzegovina found $62.85 \%$ male subjects and $32.15 \%$ female out of total 99 leukemia patients. ${ }^{11}$

The results of hemoglobin, leukocytes, and platelets in this study were not much different from the research by Sultan et al., which showed, the mean $\mathrm{Hb}$ of $8.19 \pm 2.12 \mathrm{gr} / \mathrm{dL}$, and the median of leukocytes and platelets of $43.08(0.6-372) 103 / \mathrm{mL}$ and 62.32 (3.0-576) 103/mL, respectively among AML patient population. ${ }^{12}$ Research by Allahyari et al. in Iran showed the median of $\mathrm{Hb}$, leukocytes, and platelets were 8.5 (3.8-13.1) $\mathrm{gr} / \mathrm{dL}, 24.5$ (0.4-185.7) thousand/mL and 94 (3-500) thousand/mL, respectively out of $48 \mathrm{ALL}$ patients. ${ }^{13}$

Data on the study subjects' characteristics showed a median of creatinine of $0.6(0.2-1.2) \mathrm{mg} / \mathrm{dL}$. This result indicated that creatinine levels in the study subjects were still within normal limits that there were no subjects with kidney abnormalities as exclusion criteria in this study.

The median age of the data characteristics of this study's subjects was 25 years, with the lowest age was two years, and the oldest was years. Age distribution in this study showed 21 (51.2\%) children (< 18 years) and 20 (48\%) adults (> 18 years). Research by Sanchez et al. obtained a median age of 38 years ( 2 months- 115 years). ${ }^{10}$

Types of acute leukemia in this study were divided into ALL and non-ALL, and the results showed 23 (56.1\%) ALL and 18 (43.9\%) non-ALL patients. Research by $\mathrm{Naz}$ et al. in Pakistan, which found 56 (65.11\%) patients diagnosed with ALL and 30 (34.88\%) patients diagnosed with AML of a total of 86 participants. ${ }^{14}$ Another study with similar results was found in the research by Moayeri et al., which performed a cross-sectional study of 53 acute leukemia cases with hypercalcemia. The results found $83 \%$ of $\mathrm{ALL}$ and $17 \% \mathrm{AML}$ cases. Half of the hypercalcemia cases in this study were related to $\mathrm{ALL}^{15}$

The characteristics data of the study subjects showed the average vitamin $D$ level of $26.45 \pm 1.4$ $\mathrm{ng} / \mathrm{mL}$, with $27(65.85 \%)$ subjects had a concentration of $\geq 20 \mathrm{ng} / \mathrm{mL}$, and 14 (34.15\%) subject had a concentration of $<20 \mathrm{ng} / \mathrm{mL}$. This result was similar to the research by Lee et al., which found 29 subjects with vitamin D deficiency (levels $<20 \mathrm{ng} / \mathrm{mL}$ ), 34 subjects with vitamin D insufficiency (levels 20-31.9 ng/mL) and 34 subjects with normal vitamin D (levels of $32-100 \mathrm{ng} / \mathrm{dL}$ ) in 97 cases of AML. ${ }^{16}$

Bivariate analysis showed no significant association between age and Ca ion levels in patients with acute leukemia with PR 1.393 (95\% CI: 0.395-4.917; $p=0.606$ ). An increased serum Ca ion levels can occur at all ages with factors such as parathyroid, kidney, and bone hormones, which affect Ca levels. This study's results were similar to the research by Afridi et al., comparing age with serum $\mathrm{Ca}$ ion levels in ALL and AML patients. The results showed no significant association between age and $\mathrm{Ca}$ ion levels $(\mathrm{p}>0.05) .{ }^{17}$ Another similar study was the study of Moayeri et al., which found no meaningful relationship between hypercalcemia and age, gender and length of leukemia $(p>0.05){ }^{15}$

Bivariate analysis for acute leukemia types and serum $\mathrm{Ca}$ ion levels showed no significant association with PR 1.500 (95\% CI: 0.423-5.315; $p=0.529)$. The insignificant difference might be caused by the humoral factors that underlie hypercalcemia's mechanism in acute leukemia, not only in adult T-cell leukemia/lymphoma cases but also in other hematological malignancies such as acute nonlymphocytic leukemia. ${ }^{5}$ McKay and Furman's research results showed that hypercalcemia abnormalities in malignancy could be seen in many cases, such as rhabdomyosarcoma, hepatoblastoma, and brain tumors neuroblastoma, angiosarcoma, myeloid leukemia, and ALL. There was no significant difference between ALL and AML patients with serum Ca levels $(p>0.05) .{ }^{18}$ This result was different from the research by Milionis et al., which found a significant association with serum $\mathrm{Ca}$ levels ( $p$ <.05) in ALL and AML patients. ${ }^{19}$ Inukai et al. found that in patients with acute leukemia, those with a type of hypercalcemic leukemia were B ALL with $t(17 ; 19){ }^{20}$

Bivariate analysis between PTHrP and serum $\mathrm{Ca}$ ion carried out by Chi-Square test found 17 (77.3\%) subjects with serum Ca ion levels $\geq 1.07 \mathrm{mmol} / \mathrm{l}$ and PTHrP $\geq 110.09 \mathrm{pg} / \mathrm{mL}$. There was a significant association between serum $\mathrm{Ca}$ ion levels and PTHrP $(p=0.021)$. This result was probably caused by tumor cells releasing humoral factors, such as excessive PTHrP, which stimulates bone metabolism resulting in more Ca release. Similar results were also found in research by Donovan et al. in Queensland Australia, which identified an increase in PTHrP with a simultaneous rise in serum $\mathrm{Ca}$ levels from a total of 153 subjects. PTHrP mediates the pathophysiological mechanism of hypercalcemia in malignancy, but it depends on the type of malignancy. ${ }^{21}$ 
The association between vitamin $\mathrm{D}$ and $\mathrm{Ca}$ ion was determined using the bivariate analysis to 20 (74.1\%) subjects with serum $\mathrm{Ca}$ ion levels $\geq 1.07$ $\mathrm{mmol} / \mathrm{l}$ and vitamin $\mathrm{D} \geq 20 \mathrm{ng} / \mathrm{mL}$. There was a significant association between serum $\mathrm{Ca}$ ion and vitamin D levels $(p=0.017)$. This significant association was probably caused by excessive release of PTHrP by cancer cells, causing an increase of $1.25(\mathrm{OH}) 2 \mathrm{D} 3$ in the intestine, resulting in increased $\mathrm{Ca}$ absorption, increased osteolytic bone resorption, and increased serum Ca levels. ${ }^{4,22}$ Vitamin $D$ itself functions as a type of "hormone" to increase intestinal absorption of $\mathrm{Ca}$. This substance mainly increases the formation of $\mathrm{Ca}$-binding proteins in intestinal epithelial cells and functions in the transport of $\mathrm{Ca}$ into the cytoplasm of cells. Similar research results were obtained in the research by Demirsoy et al. in Turkey, which showed a significant increase of $\mathrm{Ca}$ and vitamin D levels in 115 participants diagnosed with ALL. ${ }^{23}$ A study by McKay and Furman showed normal vitamin D levels in 17 of 25 malignant hypercalcemia patients with referral values $21-48 \mathrm{pg} / \mathrm{mL}^{18}$

Multivariate analysis with logistic regression in this study showed that PTHrP $\geq 110.09 \mathrm{pg} / \mathrm{mL}$ and vitamin $D \geq 20 \mathrm{ng} / \mathrm{mL}$ were significantly related to $\mathrm{Ca}$ ion $1.07 \mathrm{mmol} / \mathrm{l}$ levels, even after adjusting for other possible variables influencing $\mathrm{Ca}$ ion levels such as age and type of leukemia, PTHrP $\geq 110.09 \mathrm{pg} / \mathrm{mL}$ and vitamin $D \geq 20 \mathrm{ng} / \mathrm{mL}$ still showed a significant association with $\mathrm{Ca}$ ion levels $\geq 1.07 \mathrm{mmol} / \mathrm{l}$ ( $P R=0.186 ; 95 \% \quad C I: 0.038-0.899 ; \quad p=0.036$ and $P R=0.116 ; 95 \%$ CI: $0.017-0.801 ; p=0.029$ ). These results implied that PTHrP and vitamin $D$ are independent factors on serum $\mathrm{Ca}$ ion levels $\geq 1.07$ $\mathrm{mmol} / \mathrm{l}$ in patients with acute leukemia. The $\mathrm{Ca}$ ion levels are influenced by parathyroid hormone, vitamin $D$, and estrogen. The mechanism of increased Ca levels in acute leukemia is mediated by PTHrP, which will stimulate osteoblast activity, thereby increasing RANKL synthesis, which triggers osteoclast activity leading to an increase in Ca. levels. ${ }^{7}$ Other mechanisms related to vitamin $\mathrm{D}$ activity can similarly increase absorption of $\mathrm{Ca}$ in the intestine and osteolytic bone resorption leading to the rise in serum Ca levels. ${ }^{4}$

The limitations of this study were the cross-sectional design, which was used that it was unable to ascertain a causal relationship between PTHrP levels $\geq 110.09 \mathrm{pg} / \mathrm{mL}$ and vitamin $\mathrm{D} \geq 20$ $\mathrm{ng} / \mathrm{mL}$ with serum $\mathrm{Ca}$ ion levels $\geq 1.07 \mathrm{mmol} / \mathrm{l}$. Research with a cohort design was needed to obtain a hazard ratio to clarify the relationship between
PTHrP levels $\geq 110.09 \mathrm{pg} / \mathrm{mL}$, vitamin $\mathrm{D} \geq 20 \mathrm{ng} / \mathrm{mL}$, and serum $\mathrm{Ca}$ ion levels $\geq 1.07 \mathrm{mmol} / \mathrm{l}$. Research on the association between PTHrP levels, vitamin D levels and serum $\mathrm{Ca}$ ion levels in patients with acute leukemia was strongly influenced by the population and the selection criteria of research subjects such as the type of leukemia.

\section{CONCLUSION AND SUGGESTION}

This study showed an association between PTHrP, vitamin D levels, and serum Ca ion in acute leukemia patients with a cut-off level of PTHrP, vitamin D. It Ca ion serum were $\geq 110.09 \mathrm{pg} / \mathrm{mL}, \geq 20 \mathrm{ng} / \mathrm{mL}$ and $\geq 1.07 \mathrm{mmol} / \mathrm{l}$, respectively.

Based on this study, measurement of serum $\mathrm{Ca}$ ion, PTHrP, and vitamin D levels before treatment were necessary for patients with acute leukemia to prevent further complications. The association between PTHrP and vitamin D levels with $\mathrm{Ca}$ ion serum in patients with acute leukemia must still be evaluated using a cohort study design to obtain a hazard ratio to clarify the association between PTHrP and vitamin $D$ levels with $C a$ ion serum, with more attention to factors, which possibly influence the increase of $\mathrm{Ca}$ ion levels in patients with acute leukemia, such as administration of thiazide diuretics, serum protein levels, and $\mathrm{pH}$.

\section{REFERENCES}

1. de Vos J, Hassan S, Sikorska J. ABC of clinical hematology. Fourth Ed., Provan D, editor. London, Wiley, 2018; 33-39.

2. Rahmadin B, Wahid I, Yaswir R. Artikel penelitian profil penderita leukemia mieloblastik akut di bagian penyakit. J Kesehat Andalas, 2017; 6(3): 495-501.

3. Merino A, Boldú L, Ermens A. Acute myeloid leukemia: How to combine multiple tools. Int J Lab Hematol, 2018; 40: 109-19.

4. Goldner W. Cancer-related hypercalcemia. Am J Nurs, 2016; 12(5): 426-32.

5. Shu ST, Dirksen WP, Weibaecher KN, Rosol TJ. Mechanisms of humoral hypercalcemia of malignancy in leukemia/lymphoma. intechopen, 2018; 181-206.

6. Mundy GR, Edwards JR. PTH-Related Peptide (PTHrP) in hypercalcemia. 2008; 672-5.

7. Mirrakhimov AE. Hypercalcemia of malignancy: An update on pathogenesis and management. N Am J Med Sci, 2015; 7(11): 483-93.

8. Tebben PJ, Singh RJ, Kumar R. Vitamin D-mediated hypercalcemia: Mechanisms, diagnosis, and treatment. Endocr Rev, 2016; 37(5): 521-47.

9. Kulling PM, Olson KC, Olson TL, Feith DJ, Loughran TP. Vitamin $D$ in hematological disorders and malignancies. Eur J Haematol, 2017; 98(3): 187-97. 
10. Santoyo-Sánchez A, Ramos-Peñafiel CO, Martínez-Tovar A, Olarte-Carrillo I, Collazo-Jaloma J, et al. The age and sex frequencies of patients with leukemia seen in two reference centers in the metropolitan area of Mexico City. Gac Med Mex, 2016; 152(2): 208-12.

11. Hasanbegovic E, Begic N, Hasanbegovic S, Begic Z. Socio-demographic characteristics of patients with diagnosis of Leukemia in Bosnia and Herzegovina during six-year period. Mater Socio Medica, 2016; 28(6): 473.

12. Sultan S, Zaheer HA, Irfan SM, Ashar S. Demographic, and clinical characteristics of adult acute myeloid leukemia-tertiary care experience. Asian Pacific J Cancer Prev, 2016; 17(1): 357-60.

13. Allahyari A, Hashemi SM, Nazemian F, Karimi M, Kazemi MR, Sadeghi M. The relationship between risk factors and survival in adult acute lymphoblastic leukemia. Int J Cancer Manag, 2016; 9(4): e5045.

14. Naz A. Vitamin D levels in patients of acute leukemia before and after remission-induction therapy. Pakistan J Med Sci, 2012; 29(1): 10-4.

15. Moayeri H, Oloomi Z, Sambo SA. A cross-sectional study to determine the prevalence of calcium metabolic disorder in malignant childhood cancers in patients admitted to the Pediatric Ward of Vali-Asr Hospital. Acta Med Iran, 2011; 49(12): 818-23.

16. Lee HJ, Muindi J, Wei T, Wilding G, Ford LA, Sait S, et al. Subnormal vitamin $D$ levels are associated with adverse outcome in newly-diagnosed similarly-treated adult Acute Myeloid Leukemia (AML) patients. Blood [Internet]. 2010; 116(21): 1041.

17. Afridi HI, Kazi TG, Talpur FN. Correlation of calcium and magnesium levels in the biological samples of different types of acute leukemia children. Biol Trace Elem Res, 2018; 1-12.

18. McKay C, Furman WL. Hypercalcemia complicating childhood malignancies. Cancer. 1993; 72(1): 256-60.

19. Milionis HJ, Bourantas CL, Siamopoulos KC, Elisaf MS. Acid-base and electrolyte abnormalities in patients with acute leukemia. Am J Hematol, 1999; 62(4): 201-7.

20. Inukai TT, Hirose $K$, Inaba $T$, Kurosawa $H$, Hama $A$, et al. Hypercalcemia in childhood acute lymphoblastic leukemia: Frequent implication of parathyroid hormone-related peptide and E2A-HLF from translocation 17;19. Leukemia, 2007; 21(2): 288-96.

21. Donovan PJ, Achong N, Griffin K, Galligan J, Pretorius CJ, McLeod DSA. PTHrP-mediated hypercalcemia: Causes and survival in 138 patients. J Clin Endocrinol Metab, 2015; 100(5): 2024-9.

22. Kingsley $U$, Agu C, Nwosu T. Critical review of hypercalcemia. J Med Allied Sci, 2017; 7(1): 3.

23. Demirsoy U, Sarper N, Aylan Gelen S, Zengin E, Kum T, Demir $\mathrm{H}$. The association of oral vitamin $\mathrm{D}$ and calcium supplementation with bone mineral density in pediatric acute lymphoblastic leukemia patients. J Pediatr Hematol Oncol, 2017; 39(4): 287-92. 